\title{
The Emergence of Entrepreneurial Intentions in Indigenous Entrepreneurs: The Role of Personal Background on the Antecedents of Intentions
}

\author{
Ramazan Uygun ${ }^{1} \&$ Murat Kasimoglu ${ }^{1}$ \\ ${ }^{1}$ Faculty of Economics and Administrative Sciences at Biga, Canakkale Onsekiz Mart University, Turkey \\ Correspondence: Ramazan Uygun, Department of Business, Faculty of Economics and Administrative Sciences \\ at Biga, Canakkale Onsekiz Mart University, Canakkale, 17100, Turkey. Tel: 90-286-335-8738. E-mail: \\ kahramanuygun@gmail.com
}

Received: January 5, 2013

Accepted: January 21, 2013 Online Published: February 16, 2013

doi:10.5539/ijbm.v8n5p24

URL: http://dx.doi.org/10.5539/ijbm.v8n5p24

\begin{abstract}
The fact that models of entrepreneurship have generally been developed on a global scale has made the matter of explaining and assessing indigenous level experience rather difficult from the perspective of reliability and validity. It is therefore very important from an academic perspective to reveal such local scale entrepreneurial behaviours. Research was conducted in three stages. Personal backgrounds formed by factors such as role models, traits and experience, and contextual terms were addressed. Then clues regarding cognitive structures and processes were researched by focusing on how entrepreneurs recognize opportunities. Finally, factors having an influence in the formation of entrepreneurial intentions were addressed. The sampling structure of this study was entrepreneurs in the town of Biga, which is one of the main economic fields of the Canakkale region in Turkey. Findings on the research topic were obtained by evaluating entrepreneurial activities in different time periods by indigenous entrepreneurs and by conducting detailed interviews with these entrepreneurs. Using this research method made possible a more effective understanding the decision-making paradigm of the entrepreneurs. The 26 entrepreneurs analysed in the study were divided into three basic types according to the dominant factors determined following analysis of the reasons that led them to start an entrepreneurial career.
\end{abstract}

Keywords: entrepreneurship, intentions, indigenous entrepreneurs, recognition of opportunities

\section{Introduction}

Despite the high number of publications in the field of entrepreneurship, a generally accepted entrepreneurship theory (Bull \& Willard, 1995) and common agreement on the nature of the phenomenon among researchers have not yet been established (Gartner, 1989; Hornaday, 1992; Hoy \& Verser, 1994; Mitchell et al., 2004).

An attempt to determine the traits of entrepreneurs by distinguishing them from executives and society became a preferred research topic during the 1970's and 1980's (Morris, Lewis, \& Sexton, 1994). Due to the traits approach, the common traits of entrepreneurs which lead them to start a business and succeed (DeCarlo \& Lyons, 1980) could be determined and a relation between these traits and entrepreneurial behaviour could be established (Jenks, 1950).

The failure of past researches to explore entrepreneurial personality and to distinguish entrepreneurial personality clearly through the entrepreneurship process has constituted a significant blank among entrepreneurship research which needs to be filled (Mitchell et al. 2002). Controversial findings and inferences revealed by researchers (such as Litzinger, 1965; Schrage, 1965; Hornaday \& Aboud, 1971; Brockhaus, 1975; Brockhaus \& Nord, 1979; Decarlo \& Lyons, 1979; Pandey \& Tewary, 1979; Hull, Bosley, \& Udell, 1980; Brockhaus, 1980 a, b; Mescon \& Montanari, 1981; Schere, 1982; Sexton \& Bowman, 1983; Kemelgor, 1985; Perry, Meredith, \& Cunnington, 1988; Koh, 1996; Hansemark, 2003) shifted attention from the examination of traits to the examination of process (Morris et al. 1994).

\section{Recognition of Opportunities in Local Markets}

There seem to be various factors affecting entrepreneurs' recognition of opportunities and their entrepreneurial behaviours in taking advantage of these opportunities. These factors can be grouped into personal background, cognitive processes, and intentions. In this context, theoretical and empirical evaluations in the related literature 
will be addressed here briefly, and attempts will be made to develop a model aimed at factors affecting the entrepreneurial behaviours of indigenous entrepreneurs.

\subsection{Personal Background}

The first entrepreneurship researches addressed personal background from the perspective of propensity to set up an enterprise (Robinson, Stimpson, Huefner, \& Hunt, 1991). Indicators of a positive connection between previous experience and entrepreneurial behaviour were determined (Kolvereid, 1996). A great number of researchers have pointed out that entrepreneurs get their first experience in the industrial field in which they set up their enterprise. Scott and Twomey (1988) indicated that previous work experience should be regarded as an important factor in an entrepreneurial career.

Role models found an important place in entrepreneurship researches as a demographic variable (Brockhaus \& Horwitz, 1986; Cooper, 1986; Timmons, 1986; Scott \& Twomey, 1988; Scherer, Adams, Carley, \& Wiebe, 1989; Matthews \& Moser, 1995; Robinson et al. 1991; Katz, 1992; Kolvereid, 1996). Cooper (1986) presented evidence that company founders were affected by role models in their decisions to become an entrepreneur.

On the other hand, demographic models have come under criticism for many reasons. Demographic models penetrate into individuals' decision-making processes predominantly in a form of a black box. These models give very little information on how family background and social conditions influence an individual's decision making process (Kolvereid, 1996). Katz (1992) argued that role models were not applicable on a large scale. Robinson et al. (1991) argued that there wasn't any direct connection between demographic variables and entrepreneurial behaviour. Krueger (1993) emphasized also that role models could only affect entrepreneurial intentions to the extent that they affect behaviours. Kolvereid (1996) pointed out that demographic characteristics affected individuals' preference for an entrepreneurship career by means of their effects on individuals' behaviours.

Although previous research findings seem ambivalent (Dimov, 2007a), locus of control as an attribute of personal character plays an important role in the development of entrepreneurial behaviour as far as it contributes to the development of entrepreneurial intentions. The structure of locus of control is based on a general belief difference between individuals having internal and external locus of control. While individuals with an internal locus of control believe that their achievements or their destiny is under their control, individuals with an external locus of control link their achievements and their destiny with external factors (Biondo \& Macdonald, 1971; Pines \& Julian, 1972; Mitchell, Smyser, \& Weed, 1975; Zuckerman \& Gerbasi, 1977; Marsh \& Richards, 1987; Boone, Brabander, \& Witteloostuijn, 1996).

Individuals with internal locus of control possess a great ability to dominate and affect people around them (Pandey \& Tewary, 1979). They can become successful entrepreneurs by believing that they can diminish the effects of outside factors on the results with the help of common sense (Pearson \& Chatterjee, 2001). Therefore, internal locus of control is seen as an entrepreneurial trait, and it is deemed that individuals with internal locus of control have a propensity to undertake entrepreneurial activities (Jennings \& Zeithami, 1983; Kaufmann, Welsh, \& Bushmarin, 1995; Koh, 1996; Cromie, 2000; Littunen, 2000; Littunen \& Storhammar, 2000).

\subsection{Cognitive Processes}

Cognitive processes play a significant role in selecting, organizing, converting, reserving and exploiting knowledge (Schneider \& Angelmar, 1993; Ozgen \& Baron, 2007). Cognitive processes are also referred to as heuristics. In this context, heuristics are intuitional directives which generally provide quick and appropriate solutions to certain practical rules or problems (determined as standardized rules or instructive principles) (Busenitz \& Lau, 1996; Vaghely \& Julien, 2010).

Shaver and Scott (1991), Katz (1992), and Busenitz and Lau (1996) suggest that heuristics and biases are employed mostly by organization founders. Busenitz and Barney (1997) found that entrepreneurs employ heuristics more frequently and intensely than managers when making decisions, and for that they exhibit certain biases. The fact that entrepreneurs find themselves generally in new and unpredictable conditions decreases their chance of reaching information structures like historical trends and past performances (Keh, Foo, \& Lim, 2002). Entrepreneurs under these conditions make decisions with constricted information in their hands (Busenitz \& Barney, 1997). According to Simon and Houghton (2002), individuals employ heuristics because of the highly uncertain conditions of the start-up decision-making process and thereby biases resulting from those heuristics may lead to a perceived level of risk relating to the decision which is lower than actual. This also may positively affect individuals' preferences about the entrepreneurship career path (Carolis \& Saparito, 2006). Some criterion could be applied to determine heuristics and biases which influence a start-up decision. If heuristics and biases 
emerge in a newly encountered situation, reducing individuals' risk perceptions while engaging on the assessment phase of decision making, then it is obvious that they are affecting the start-up decision (Simon, Houghton, \& Aquino, 1999).

\subsection{Entrepreneurial Intentions}

Entrepreneurial intentions are of vital importance in understanding the entrepreneurship process in a general sense due to their key role in opening the door to the establishment of a new enterprise (for example: Bird, 1988; Krueger, 1993; Krueger \& Carsrud, 1993; Krueger 2000). Intention implies planned behaviour. In other words, an individual's intent to create an organization means starting to plan as a result of this behaviour (Hmieleski \& Corbett, 2006). In this framework, intention can be defined as a mental state moderating an individual's attention, experience and behaviours towards realization of a certain intention and developing methods to achieve it (Bird \& Jelinek, 1988). Intentions take shape due to an individual's perceptions of social and physical environments; and perceived contexts, expectations, attitudes, beliefs and choices influence the development of intentions and, moreover, these perceptions may be affected by original factors belonging to the individual's background (Boyd \& Vozikis, 1994).

In entrepreneurship literature, there appear to be three models of entrepreneurial intentions (Shook, Priem, \& Mcgee, 2003): The Shapero (1982) model of the entrepreneurial event, the Ajzen (1987) theory of planned behaviour (TPB), and the Bird (1988) model of implementing entrepreneurial ideas.

In the model of Bird (1988), personal and contextual conditions interact with the rational and intuitive thought system in the process of the formation of entrepreneurial intentions. This culminates in the creation of organization. Contextual conditions are made up of the individual's social, political and economic conditions. Individual conditions are made up of the individual's personal history, personality and abilities. New enterprise initiation intention can be the outcome of the rational, analytic and causal thinking system as well as the intuitive and heuristic thinking system. As time goes by, entrepreneurial intentions give birth to entrepreneurial behaviour (Bird, 1988).

Boyd and Vozikis (1994) broadened the model of Bird by including the effects of self-efficacy, which is affected by previous work experience, entrepreneurial role models and social support. Entrepreneurial self-efficacy affects the development of entrepreneurial intentions, and it develops the relationship between entrepreneurial intentions and entrepreneurial behaviours (Shook et al. 2003; Vaghely \& Julien, 2010).

According to the Shapero's model (1982), human behaviours are guided by inertia until the emergence of a displacement. This displacement can be negative (losing one's job) or positive (inheritance). Displacement quickens the transformation of a behaviour, and the individual who is going to make a decision begins to research on choosing the behaviour yielding the best results among an alternative behaviour group. Entrepreneurial intentions are basically based on two factors according to this model. Firstly, starting of an enterprise should be perceived as a credible action, i.e. starting a new enterprise should be seen as a credible opportunity. Secondly, the start of a new enterprise requires a sort of precipitating act. Credibility requires perceived desirability and perceived feasibility. Shapero (1982) defined perceived feasibility as the belief of how competent the individual is to start a new enterprise, and the attractiveness (intra and extra personal) of starting a venture. Propensity to act is the personal disposition to act upon one's decision. However, propensity to act should be seen as a moderate effect rather than a direct antecedent like feasibility and desirability (Krueger, 1993).

Perceived desirability, perceived feasibility and propensity to act were presented as the antecedents of entrepreneurial intentions (Peterman \& Kennedy, 2003). Empirical proofs generally support Shapero's model (Krueger, 1993; Krueger \& Brazeal, 1994; Krueger, Reilly, \& Carsrud, 2000).

Ajzen (1987)'s TPB specifies three attitudinal antecedents of intentions: attitude toward the behaviour, subjective norms, and perceived behavioural control. Krueger and Carsrud (1993) adapted these constituents into entrepreneurship behaviour and presented them as the perceived attractiveness of entrepreneurial behaviour (perceptions of likely intrinsic and extrinsic personal outcomes and expectations), perceived social norms about entrepreneurial behaviour (extra influences on the person), and perceived self-efficacy/control about entrepreneurial behaviour (personal perception of the behaviour's feasibility).

Krueger (1993) and Krueger \& Brazeal (1994) have compared Shapero's and Ajzen's models, and they have found a significant confluence. According to them, the perceived feasibility in Shapero's model is equivalent to perceived behavioural control in PDT. All of these concepts are also related with perceived self-efficacy. Subjective norm and attitude concepts in PDT overlap with the perceived desirability concept in Shapero's 
model. However, the framework presented by Ajzen's model does not contain an open willpower criteria similar to action propensity.

Propensity to act reflects voluntary constituent of intentions. Shapero's concept of propensity to act when encountered with an opportunity depends on an individual's perceptive control and particularly his desire to gain control by acting. Its effects can be both direct and indirect. Therefore, its role in the intention model is the role of moderator. Before forming a serious intention, the individual must see the availability of the possibility for acting. Thus, the propensity to act acquires a direct effect (Krueger, 1993).

Completely subjective situations precipitating the action (e.g. reaching the age of 40 , being fired from a job, winning a contract), which end an individual's inertia and reflect a sort of displacement, precipitate going into action. The manner in which we react to this displacement depends entirely on our perception of this event's effects. At the same time, individuals' reactions depend on the options perceived (Krueger, 2000). Shapero (1982) notes that perceptions are of critical importance. Events changing life style such as losing one's job or immigration precipitate entrepreneurial actions. In these circumstances, individuals' perceptions of conditions rather than the individuals themselves change (Krueger \& Brazeal, 1994).

Researches have indicated that particular external variables play a triggering/precipitating role in transforming these intentions into behaviours (Shapero, 1982; Krueger \& Brazeal, 1994). In the case of intentions not being agitated by a triggering event, entrepreneurial potential does not transform into entrepreneurial intentions (Shook et al. 2003). External factors may influence the intention-behaviour relationship by means of ensuring the realization of intentions or their precipitating. While one of these factors can be the perception of availability of required resources, another factor can be the propensity to act (Krueger, 2000).

While the Model of the Entrepreneurial Event was developed directly for entrepreneurial behaviour, the theory of planned behaviour was developed in general for human behaviour and adapted later by entrepreneurship researchers (Krueger \& Brazeal, 1994; Shook et al. 2000). In this study, the Model of Entrepreneurial Event revised by Krueger was used. Furthermore, Krueger et al. (2000) reviewed both TPB and the Model of the Entrepreneurial Event, and they emphasized the validity of both models and their importance in understanding entrepreneurship process.

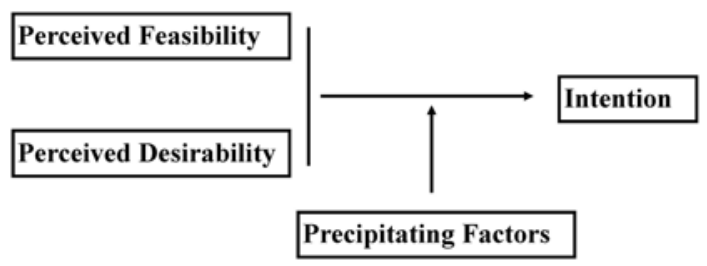

Figure 1. Simplified Shapero \& Krueger intentions model

\section{Model of Empirical Study}

In this study, the basic outline of the subject was addressed by focusing on research in the literature related to entrepreneurs' recognition of opportunities and their seizing these opportunities; this was followed by analysis of the indigenous entrepreneurs within the framework of these parameters. Research was conducted in three stages. In the first stage, personal backgrounds formed by factors such as role models, traits and experience, social networks, and contextual terms were addressed. In the second stage, clues regarding cognitive structures and processes were researched by focusing on how entrepreneurs recognized opportunities. In the last stage, factors having an influence on the formation of entrepreneurial intentions, which underlie entrepreneurs' behaviour in setting up or taking over a company, were deeply analysed and questions such as what these factors were, and which personal or contextual factors affected their formation and triggering, were addressed. The Entrepreneurial Behaviour Model is adapted from Uygun (2006)'s study. 


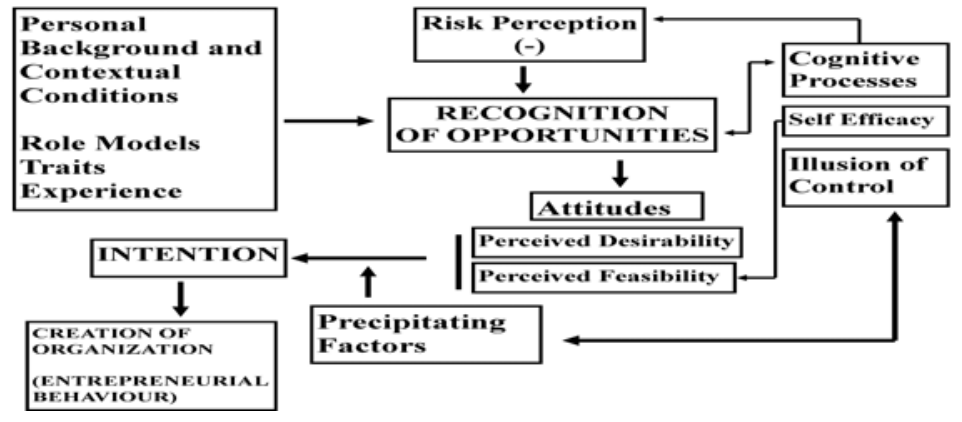

Figure 2. Entrepreneurial behaviour model

\subsection{Sampling Structure and Analysis of Data}

The sampling structure of this study is entrepreneurs in Biga, which is one of the main economic fields in Canakkale region. The reason for limiting this research particularly to the Biga district, and the analysis of it in a narrow frame, is the difficulties created in reaching a sampling structure. Furthermore, Biga is more qualified than other districts of Canakkale province in producing and creating entrepreneurs. This superiority becomes more obvious after observation of the number of enterprises and the roots of entrepreneurs dominant in the region. In this context, entrepreneurs and businessman registered in the Chamber of Commerce and Industry were especially taken into consideration, and their emergence, development and entrepreneurship models were addressed in the research. Twenty-six members out of nearly 200 members of Biga Chamber of Commerce and Industry were evaluated in the context of this study.

Interview holds an important place in the analysis of decisions taken by entrepreneurs and businessmen in the business world. The thoughts expressed in the interviews with entrepreneurs in this study present important information about their entrepreneurial attitudes and behaviours, risk perceptions and recognition opportunities. We sought to reveal findings about the research topic by evaluating entrepreneurial activities realized in different periods by indigenous entrepreneurs and conducting in-depth interviews with these entrepreneurs. The most reliable method to explain this process is the use of these records or cases. Each interview lasted between 1 and $2 \mathrm{~h}$. Interview is an approach providing direct data regarding the subject. Moreover, it is a model allowing the examination of present conditions (Graaf, 2006). Like Ucbasaran, Wright and Westhead (2003), this study used interviews as case studies to explore origins of entrepreneurial intentions.

Using this research method, the chance of understanding the decision making paradigm of entrepreneurs effectively by starting with interview is possible. Furthermore, these interviews not only give information on the entrepreneurship paradigm, but also provide information on the conditions surrounding entrepreneurs and business values. Due to difficulties encountered in collecting data the effect of background on entrepreneurs' recognition and perception of opportunities was examined through interviews. At the end of the research, we aimed to present different classifications about the exhibition of entrepreneurial behaviours based on works of Eisenhardt (1989) and Yin (1989) used the interviews as cases.

Table 1. Demographic qualities of sampling

\begin{tabular}{|c|c|c|c|c|c|}
\hline Cases & Sex & Education & Entrepreneurship Rank & Active Sector(s) & $\begin{array}{l}\text { Foundation date } \\
\text { of the Enterprise }\end{array}$ \\
\hline 1 & M & High School & Founder entrepreneur & Manufacturing & 1965 \\
\hline 2 & M & University & Founder entrepreneur & Ceramics & 1983 \\
\hline 3 & M & High School & 3rd Generation Founder Entrepreneur-New Product & Machine production & 1934 \\
\hline 4 & M & $\begin{array}{l}\text { Primary } \\
\text { School }\end{array}$ & Founder entrepreneur & Leather Processing & 1974 \\
\hline 5 & M & $\begin{array}{l}\text { Primary } \\
\text { School }\end{array}$ & Founder entrepreneur & Turkish Delight & 1972 \\
\hline 6 & M & Primary & 3rd Generation Founder Entrepreneur-New Product & Spice & 1912 \\
\hline
\end{tabular}




\begin{tabular}{|c|c|c|c|c|c|}
\hline & & School & & & \\
\hline 7 & M & $\begin{array}{l}\text { Primary } \\
\text { School }\end{array}$ & 2nd Generation Founder Entrepreneur-New Sector & Furniture & 1950 \\
\hline 8 & M & $\begin{array}{l}\text { Primary } \\
\text { School }\end{array}$ & Founder entrepreneur & Leather Processing & 1985 \\
\hline 9 & $\mathrm{M}$ & University & 2nd Generation Founder Entrepreneur-New Product & Printing House & 1972 \\
\hline 10 & M & $\begin{array}{r}\text { Primary } \\
\text { School }\end{array}$ & Founder entrepreneur & $\begin{array}{c}\text { Transportation } \backslash \text { Stone } \\
\text { grinding }\end{array}$ & 1947 \\
\hline 11 & M & $\begin{array}{l}\text { Primary } \\
\text { School }\end{array}$ & 2nd Generation Founder Entrepreneur & $\begin{array}{c}\text { Transportation } \backslash \text { Stone } \\
\text { grinding }\end{array}$ & 1947 \\
\hline 12 & M & $\begin{array}{l}\text { Primary } \\
\text { School }\end{array}$ & Founder entrepreneur & Textile & 1939 \\
\hline 13 & M & $\begin{array}{l}\text { Primary } \\
\text { School }\end{array}$ & Founder entrepreneur & Textile Painting & 1974 \\
\hline 14 & M & High School & Founder Entrepreneur & Construction & 1973 \\
\hline 15 & M & High School & 2nd Generation -New Sector & $\begin{array}{c}\text { White Appliances } \\
\text { Trader }\end{array}$ & 1963 \\
\hline 16 & M & $\begin{array}{r}\text { Primary } \\
\text { School }\end{array}$ & 2nd Generation Entrepreneur & $\begin{array}{c}\text { Flour Factory and } \\
\text { Sale }\end{array}$ & 1968 \\
\hline 17 & M & $\begin{array}{l}\text { Primary } \\
\text { School }\end{array}$ & Founder entrepreneur & $\begin{array}{c}\text { Flour and Feeding } \\
\text { Sale }\end{array}$ & 1978 \\
\hline 18 & M & University & 2nd Generation Founder Entrepreneur-New Sector & Shoe Making & 1974 \\
\hline 19 & M & $\begin{array}{r}\text { Primary } \\
\text { School }\end{array}$ & 2nd Generation Founder Entrepreneur-New Product & $\begin{array}{l}\text { Dairy Products and } \\
\text { Dessert Factory }\end{array}$ & 1930 \\
\hline 20 & M & University & Founder entrepreneur & Health- Medicine & 1974 \\
\hline 21 & M & University & 3rd Generation Founder Entrepreneur-New Sector & $\begin{array}{l}\text { Selling Dry Goods } \\
\text { and Notions }\end{array}$ & 1900 \\
\hline 22 & M & University & Founder entrepreneur & $\begin{array}{l}\text { Flour and Feeding } \\
\text { Sale }\end{array}$ & 1987 \\
\hline 23 & M & $\begin{array}{r}\text { Primary } \\
\text { School }\end{array}$ & Founder entrepreneur & $\begin{array}{l}\text { Shoe Making } \\
\text { Furniture }\end{array}$ & 1960 \\
\hline 24 & M & High School & 2nd Generation Founder Entrepreneur-New Sector & $\begin{array}{c}\text { Commerce (Various } \\
\text { Sectors) }\end{array}$ & 1948 \\
\hline 25 & M & High School & 2nd Generation Founder Entrepreneur-New Product & Manufacturing & 1969 \\
\hline 26 & M & $\begin{array}{c}\text { Primary } \\
\text { School }\end{array}$ & Founder entrepreneur & Clothing Industry & 1960 \\
\hline
\end{tabular}

Table 2. Indigenous entrepreneurial values

\begin{tabular}{ll}
\hline Values Belonging to Individuals & Values Relating to the Business Structure \\
\hline $\begin{array}{l}\text { Being a member of notables, Coming from a noble family, } \\
\text { Political support }\end{array}$ & $\begin{array}{l}\text { Following father's profession and family } \\
\text { tradition }\end{array}$ \\
Sell -Buy logic & $\begin{array}{l}\text { Tendency towards commerce instead of industrial } \\
\text { investment }\end{array}$ \\
Disinterest in partnership & $\begin{array}{l}\text { Using gold adornments received as wedding gift } \\
\text { as capital }\end{array}$ \\
Negative attitude towards scientific management thought & Tendency to employ family members \\
$\begin{array}{l}\text { Avoidance of risk and taking decisions bringing short term } \\
\text { profits }\end{array}$ & Small scale production and activities \\
\hline
\end{tabular}




\section{Findings}

The findings of the research have been assessed according to factors such as experience, role models, locus of control, heuristics such as self-efficacy and illusion of control, social networks, entrepreneurial intention and its antecedents. Antecedents of entrepreneurial intention, perceived desirability, and feasibility were found in all the cases. However, how do the experience and role models influence these antecedents primarily? The role of personal background in the formation of entrepreneurial intentions will be explained based on the findings.

Table 3. Findings

\begin{tabular}{|c|c|c|c|c|}
\hline Cases & $\begin{array}{l}\text { The sector which they (case } \\
\text { actors) gained experience }\end{array}$ & $\begin{array}{l}\text { The sector which they (case } \\
\text { actors) launched their } \\
\text { business }\end{array}$ & $\begin{array}{l}\text { The role } \\
\text { models and } \\
\text { their business } \\
\text { sectors which } \\
\text { they operated }\end{array}$ & $\begin{array}{l}\text { Triggering } \\
\text { event or } \\
\text { precipitating } \\
\text { factors }\end{array}$ \\
\hline 1 & $\begin{array}{l}\text { worked as a supervisor in a } \\
\text { gun-rifle factory }\end{array}$ & $\begin{array}{l}\text { brought the first power lathe } \\
\text { to the Biga region - } \\
\text { Manufacturing }\end{array}$ & His father $\sqrt{ }$ & \\
\hline 2 & $\begin{array}{l}\text { worked in the ceramics factory } \\
\text { of the district as a manager for } \\
\text { years }\end{array}$ & Ceramics & His father $\sqrt{ }$ & \\
\hline 3 & $\begin{array}{l}\text { growing up in the business } \\
\text { and took over the family } \\
\text { businesses }\end{array}$ & Machine production & $\begin{array}{l}\text { His father } \\
\text { Machine } \\
\text { production }\end{array}$ & \\
\hline 4 & work in a leather tannery & Leather Processing & $\begin{array}{l}\text { His father } \sqrt{ } \\
\text { master }\end{array}$ & $\sqrt{ }$ \\
\hline 5 & work in a candy making store & Turkish Delight & $\begin{array}{l}\text { craftsmen } \\
\text { candy making }\end{array}$ & $\sqrt{ }$ \\
\hline 6 & Took over & Spice & $\begin{array}{l}\text { His father } \\
\text { Spice }\end{array}$ & $\sqrt{ }$ \\
\hline 7 & Took over & Furniture & $\begin{array}{l}\text { His father } \\
\text { Furniture }\end{array}$ & \\
\hline 8 & $\begin{array}{l}\text { began his career as an } \\
\text { apprentice in a leather } \\
\text { processing store }\end{array}$ & Leather Processing & $\begin{array}{l}\text { Master } \\
\text { craftsmen } \\
\text { leather } \\
\text { processing }\end{array}$ & \\
\hline 9 & Took over & Printing House & $\begin{array}{l}\text { His father } \\
\text { Printing House }\end{array}$ & \\
\hline 10 & $\begin{array}{l}\text { i gained the experience for my } \\
\text { future career during my } \\
\text { mandatory military service: } \\
\text { driving }\end{array}$ & $\begin{array}{l}\text { Transportation } \quad \backslash \quad \text { Stone } \\
\text { grinding }\end{array}$ & His father $\sqrt{ }$ & \\
\hline 11 & Took over & $\begin{array}{l}\text { Transportation } \quad \backslash \quad \text { Stone } \\
\text { grinding }\end{array}$ & $\begin{array}{l}\text { His father } \\
\text { Transportation } \backslash \\
\text { Stone grinding } \\
\text { master }\end{array}$ & \\
\hline 12 & learned weaving & Textile & $\begin{array}{l}\text { craftsmen } \\
\text { weaving }\end{array}$ & $\sqrt{ }$ \\
\hline 13 & $\begin{array}{l}\text { learned weaving from my } \\
\text { entrepreneur father, but started } \\
\text { my own business in textile } \\
\text { dyeing. }\end{array}$ & Textile Painting & $\begin{array}{l}\text { His father } \\
\text { Textile }\end{array}$ & $\sqrt{ }$ \\
\hline 14 & $\begin{array}{l}\text { started his career as a bus } \\
\text { conductor }\end{array}$ & $\begin{array}{l}\text { Construction }(\text { His first } \\
\text { venture was a transportation } \\
\text { firm) }\end{array}$ & $\begin{array}{l}\text { Master } \\
\text { craftsmen } \\
\text { transportation }\end{array}$ & $\sqrt{ }$ \\
\hline 15 & Took over & White Appliances Trader & $\begin{array}{l}\text { His father } \\
\text { White }\end{array}$ & \\
\hline
\end{tabular}




\begin{tabular}{|c|c|c|c|c|}
\hline 16 & Took over & Flour Factory and Sale & $\begin{array}{l}\text { Appliances } \\
\text { Trader } \\
\text { His mother as a } \\
\text { master } \\
\text { craftsmen Flour } \\
\text { Factory and } \\
\text { Sale }\end{array}$ & $\sqrt{ }$ \\
\hline 17 & $\begin{array}{l}\text { gained my experience in the } \\
\text { agricultural sector }\end{array}$ & Flour and Feeding Sale & His father $\sqrt{ }$ & $\sqrt{ }$ \\
\hline 18 & Took over & Shoe Making & $\begin{array}{l}\text { His father Shoe } \\
\text { Making }\end{array}$ & \\
\hline 19 & Took over & $\begin{array}{l}\text { Dairy Products and Dessert } \\
\text { Factory }\end{array}$ & $\begin{array}{l}\text { His father } \\
\text { Dairy Products } \\
\text { and Dessert } \\
\text { Factory }\end{array}$ & \\
\hline 20 & - & Health- Medicine & $\begin{array}{l}\text { His grandfather } \\
\text { and uncle } \sqrt{ }\end{array}$ & \\
\hline 21 & Took over & $\begin{array}{l}\text { Selling Dry Goods and } \\
\text { Notions }\end{array}$ & $\begin{array}{lr}\text { His } & \text { father } \\
\text { Selling } & \text { Dry } \\
\text { Goods } & \text { and } \\
\text { Notions } & \end{array}$ & \\
\hline 22 & - & Flour and Feeding Sale & - & $\sqrt{ }$ \\
\hline 23 & $\sqrt{ }$ & $\begin{array}{l}\text { Shoe Making } \\
\text { Furniture }\end{array}$ & $\begin{array}{l}\text { master } \\
\text { craftsmen } \sqrt{ }\end{array}$ & $\sqrt{ }$ \\
\hline 24 & Took over & Commerce (Various Sectors) & $\begin{array}{l}\text { His father } \\
\text { Commerce }\end{array}$ & \\
\hline 25 & Took over & Manufacturing & $\begin{array}{l}\text { His father } \\
\text { Manufacturing }\end{array}$ & \\
\hline 26 & $\sqrt{ }$ & Clothing Industry & $\begin{array}{l}\text { Master } \\
\text { craftsmen } \sqrt{ }\end{array}$ & \\
\hline
\end{tabular}

\subsection{Experience-Self Efficacy-Feasibility Relation}

Researchers have found that entrepreneurs get their first experience in the industrial field in which they start an enterprise. Scott and Twomey (1988) indicated the importance of previous work experience in a business career. The majority of entrepreneurs had previous work experience in the sector they started their venture (Brockhaus \& Horwitz, 1986). Matthews and Moser (1995) presented a statistical relationship between experience gained in small enterprises and preferring entrepreneurship career as the owner of a small enterprise. Enterprises in the region covered in this research are also predominantly small-scale businesses, and all of the enterprises contained in the sampling have an employee volume of three to fifty employees depending on the enterprise.

An assessment of the cases revealed the important role played by experience in starting up a business venture. In most cases, entrepreneurs generally launched their own ventures in the areas they had experience. It is highly important for the entrepreneurs to have had incubation in the sector in order to create a business venture on a local scale. This can easily be seen from the relation between entrepreneurs' experience areas and their business ventures addressed in the following cases, where there is evidence indicating the positive influence of experience on the exhibition of entrepreneurial behaviour:

CASE 5: ...I started my career by working as an apprentice in a candy making store during school vacations....I worked as an apprentice for three more years after finishing primary school in 1960 . After some time, i established my own candy making company in 1972.

CASE 6: ...I left primary school to work in my father's spice store....I took over this company and improved it....

CASE 10: ...I was a driver during my military service. I am one of the oldest drivers in Biga, and learnt to drive during my military service...

CASE 16: ...My mother was a farmer, and i learned everything about farming from my mother.... 
The fundamental factor for the willingness of an individual to dedicate himself or herself to work requiring highconcentration and effort is belief in activating his physical, intellectual and emotional capacity in order to achieve success, and this process is called self-efficacy (Eden \& Aviram, 1993). Self-efficacy points to the successful realization of necessary behaviours by an individual (Markman, Balkin, \& Baron, 2002), and individuals with this characteristic can achieve high performance (Shepherd \& Krueger, 2002). Self-efficacy refers to individual skills and the ability to control present conditions. Therefore, lack of self-efficacy means the absence of behaviour, and this makes perceived self-efficacy the most important determiner of career selection (Krueger \& Brazeal, 1994).

Individuals measure the relationship between their perception of skills and the qualities the work demands in themeasurement of their skills for performance demonstrations (Cervone, 2000). The most effective way of developing strong self-efficacy is experience (Erikson, 2003). Self-efficacy expresses the skill an individual perceives in himself in order to realize a targeted behaviour. Therefore, this perceived self-efficacy becomes the most important determiner in career selection (Krueger \& Brazeal, 1994). Experience gained in a particular sector has an important effect on the entrepreneurs' self-efficacy.

In this context, entrepreneurs in all of the cases covered in the research had launched their business ventures in the fields they had experience or took over other business ventures. During the interviews, they stated that they already had the necessary knowledge and skills for the venture, and there was no risk in their undertakings. They said that the course to be taken was to reach the necessary resources.

On the other hand, self-efficacy formed by the experience gained in a sector is related with perceived feasibility, which is the antecedent of behavioural intention. Self-efficacy influences the development of entrepreneurial intentions and develops the relationship between entrepreneurial intentions and entrepreneurial behaviours (Shook et al. 2003; Dimov, 2007b; Townsend, Busenitz, \& Arthurs, 2010). Krueger and Brazeal (1994) compared Shapero's Entrepreneurial Event Model with Ajzen's PBT and found a significant point of intersection. They claimed that the perceived feasibility in Sapero's model is the equivalent of perceived behavioural control in PBT. All of these concepts are also related with self-efficacy.

As is seen in Figure 3, experience which is assessed in the context of personal background influences perceived feasibility, and the intention related to entrepreneurial behaviour positively. In 24 of the 26 cases analysed, the sector in which experience was gained and the sector of new business venture was the same.



Figure 3. The Effect of experience on entrepreneurial intentions of indigenous entrepreneurs

It is possible to say that an entrepreneur's having an incubator in the sector is highly important in the emergence of business ventures, especially on a local scale.

However, how does the experience affect entrepreneurial attitude, intention and behaviour in terms of the attitude-intention-behaviour model? Experience strengthens the self-efficacy of the individual, affects feasibility which is perceived as one of the antecedents of entrepreneurial intentions in a positive way, and also supports themanifestation of entrepreneurial behaviour.

Proposition 1: Experience strengthens self-efficacy, causes the formation of entrepreneurial intentions by affecting self-efficacy, increases perception of self-efficacy, affects perceived feasibility positively, and causes the exhibition of entrepreneurial behaviour.

The Experience-Self efficacy-Perceived Feasibility relationship is observed clearly in 24 of the cases except case 20 and 22. Entrepreneurs in cases 20 and 22 set up their enterprises in sectors they had no experience in. The entrepreneur in Case 20 had an education in pharmacology and started his venture in this field. However, the entrepreneur in this case can be seen as a person who acquired the know-how of his profession in a Faculty of Pharmacology instead of master-apprentice type training. It is necessary to have a higher education in pharmaceutics for development and experience in this sector; whereas it is more important to learn the business working with a master rather than having a higher education for enterprises like manufacturing. Case 22 was active in poultry farming while he was a teacher. Then he resigned from his job as teacher and opened a store selling animal feed, flour, etc. Although there is no direct link in this case between poultry farming and his 
enterprise in animal feeding stuff, ultimately, experience is also valid for this case.

Upon evaluation of all these cases, it is revealed that all of the entrepreneurs had previous experience in the sectors in which they set up their enterprises. During interviews, the entrepreneurs emphasized that they were experienced in the sectors in which they established their enterprises. They trusted their skills (self-efficacy), and this affected their entry into an entrepreneurship career positively (perceived feasibility). In this context, theoretical structure is supported by empirical research, and $\mathrm{H} 1$ is found to be valid for the entire sampling.

\subsection{Role Models-Perceived Feasibility and Desirability Relation}

Role models have an important place in entrepreneurship researches as a demographic variable. Cooper (1986) presented proofs that founders of ventures are affected by role models in their decision to become entrepreneurs. The existence of a successful role model encourages entrepreneurship efforts (Brockhaus \& Horwitz, 1986; Holcomb, Ireland, Holmes, \& Hitt, 2009). Following are the excerpts from the interviews regarding the relation between role model and entrepreneurial behaviour:

CASE 6: ... I spent my life making sieves and baskets that learned to make from my father...

CASE 3: ... I am a third generation entrepreneur, and have grown up in this business since my childhood....

CASE 12: ....My father was illiterate and working in trade....I learnt how to weave in Istanbul. I started to work in the weaving industry when $i$ was 15 .... My boss generally gave me the duty of taking care of the business while he was travelling....I started my venture in textiles in 1940....

\section{CASE 15: ... my father was a master in my profession....}

The presence of an entrepreneurial role model will affect the state of self-efficacy in a positive way. The higher the level of self-efficacy provided by the role model, the stronger entrepreneurial intentions would be (Erikson, 2003). According to Scherer et al. (1989), Krueger (1993), and Krueger and Carsrud (1993) role models can affect entrepreneurial intentions only by affecting attitudes. The attitude of the individual towards entrepreneurship would be affected implicitly from the presence of role models (Peterman \& Kennedy, 2003). However, role models can only contribute to the development of entrepreneurial intentions as long as they affect perceptions of desirability and feasibility (Krueger, 2000).

In the figure below, the effects of role models on entrepreneurial intentions in the context of personal backgrounds are shown.

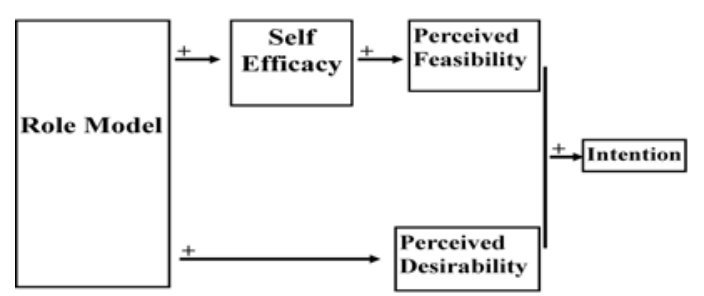

Figure 4. The effect of role models on indigenous entrepreneurs

Proposition 2: If the entrepreneur started or took over his enterprise in the same sector in which his role model is active, the role model would primarily strengthen self-efficacy, and increasing self-efficacy would cause the formation of entrepreneurial intention as well as exhibition of entrepreneurial behaviour by affecting the perceived feasibility positively.

Proposition 3: If the entrepreneur started his enterprise in a sector different from his role model's sector, the role model would cause the formation of entrepreneurial intention as well as exhibition of entrepreneurial behaviour by primarily affecting the perceived desirability positively.

In the 19 out of 26 cases (13 fathers and 6 master craftsmen) analysed, the role model affecting the entrepreneur is active in the same sector the entrepreneur would choose in the future. Entrepreneurs established or took over their enterprises in the sectors in which their role models were already active. These role models affected feasibility positively through self-efficacy. In five of the cases, there is an entrepreneur role model in the family. However, the entrepreneur established his enterprise in a different sector from his role model's sector. There is 
no role model in one case.

In the cases that a father's profession is followed $(3,6,7,9,11,15,16,18,19,21,24,25)$, the role model is the father of entrepreneur. Thus, an entrepreneurship career in these cases was realized by continuation of the father's profession. Present enterprises were taken over. In Case 13, the role model of the entrepreneur is his father, but he established his enterprise in textile painting rather than his father's sector of weaving industry. Although his sector is not the same sector as his father's, he observed and learnt the work's application and characteristics from his role model. In cases 5, 8, 12, 14, 23 and 26, the role models of the entrepreneurs are the masters they worked with as an apprentice.

In the cases mentioned above, entrepreneurs started their enterprises in sectors where their role models were already active. Therefore, the role model firstly affected self-efficacy, and then self-efficacy caused a positive effect on perceived feasibility. It can be said particularly for these cases that the role model is primarily effective on perceived feasibility (H2). Entrepreneurs acquire self-efficacy through their role models, whom they observe and share experience with. Thereby self-efficacy causes the entrepreneurs to set up or take over enterprises in the same sector their role models are active in by increasing perceived feasibility.

In cases $1,2,4,10,17$ and 20, although there is a role model in the family, entrepreneurs had chosen different sectors for their enterprises. Thereby it can be stated that role models in these cases had a direct influence on perceived desirability, because they affected the selection of entrepreneurship as a career. Hereby it can be stated that the role model affects self-efficacy (at least in the direction that entrepreneurship is feasible). However, sufficient data could not be collected from the sampling regarding this issue. Role models primarily increased perceived desirability in these cases. They function as a sort of encouraging mechanism in the selection of entrepreneurship as a career. Moving forward from this point, data supporting H3 was collected.

On the other hand, there is no role model in Case 22. He was active first in poultry farming, and then in husbandry while he was a teacher. Finally, he resigned from his job as a teacher and opened his store selling animal feeding stuff, flour, etc. At this point, there is no role model in the family or mentor system. However, a close look into locations he worked as a teacher reveals that he worked as a teacher in the villages of Biga district. The easiest work requiring not much capital in the villages is poultry farming, needing little in the way of supervision or capital. Most probably, there was more than one role model instead of just one in this case, because the place in which poultry farming changed the career of Case 22 is a place where husbandry activities are common practice. Moving from this point, although it has not been determined clearly, the role model for this case may be a neighbour, friend or even a student living in the villages he worked in as a teacher.

\subsection{Locus of Control - Illusion of Control - Precipitating Factors Relationship}

Illusion of control is formed under conditions when skill is not being used as an effective factor, and luck is playing a leading role (Simon et al. 1999; Baron \& Ward, 2004). It is a tendency emerging in the case of individuals' overemphasizing that their performance will rise by means of their skills (Schwenk, 1984; Keh et al. 2002).

Shapero (1982) underlined that completely subjective situations may precipitate the action (for example, a 40th birthday). He also noted that some common precipitating events such as losing one's job or a significant business contract, which reflects changing locations by ending an individual's inertia, precipitate going to action. Our reaction to this location change is completely dependent on our perception of the effects of this event; our reactions depend on our perception of options (Krueger, 2000). In the following paragraphs, excerpts from the interviews and findings showing a relationship between internal locus of control, illusion of control, and precipitating factors will be discussed.

CASE 13: ....i wanted to buy Pikanol brand textile machines when they first came into Turkey and Istanbul. I came to the stage of a contract for 4-6 machines, but my father didn't sign the contract....After the end of this family partnership in 1974... Having experience in the textile industry, i started to produce canvas....

CASE 23: ....I ran away from my family just one year before my military service due to disagreements with my father.... I took new decisions about my life and went into the shoe making sector as an apprentice...

According to information given in the paragraphs above and the precipitating or triggering factors seen in ten cases, it can be stated that the entrepreneurs mentioned have internal locus of control. This personality characteristic contributes to the development of entrepreneurial intentions by means of illusion of control. 


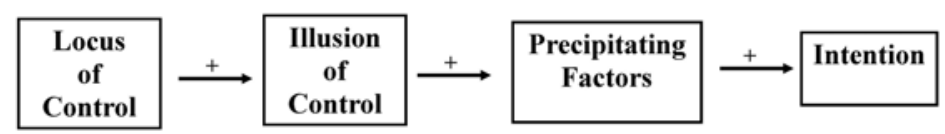

Figure 5. The effect of internal locus of control on entrepreneurial intentions of indigenous entrepreneurs

Proposition 4: Internal locus of control as a personality characteristic increases the illusion of control; Illusion of control strengthens the individual's intention of exhibiting an entrepreneurial behaviour by going into interaction when encountered with triggering or precipitating components of intention.

In ten cases (cases $4,5,6,12,13,14,16,17,22,23$ ), it can be said, based on the precipitating or triggering factors, that entrepreneurs in these cases have internal locus of control, and this personality characteristic contributes to the development of entrepreneurial intentions by means of illusion of control. Potential entrepreneurs have a tendency to bring some uncertainties under their control or to control the uncertainty they face during their assessment of emerging changes, possibilities, and opportunities in their decision making process. This control requires a background with an internal locus of control. Illusion of control becomes active in their cognitive processes and interacts with precipitating factors in producing entrepreneurial intentions. The discovery of triggering or precipitating factors in only ten cases does not mean that entrepreneurs in the other sixteen cases do not have internal locus of control, or they do not have a tendency for illusion of control, because, firstly, precipitating or triggering factors were examined in determining the correlation of internal locus of control, illusion of control, and precipitating factors. Following the discovery of this correlation, the existence of illusion of control and internal locus of control is evaluated theoretically by examining the case backwards. Eventually, this relation is logical in theory.

\section{General Evaluation of Research and Conclusions}



Figure 6. The emergence of indigenous entrepreneurship

The 26 entrepreneurs analysed in the study have been divided into three basic types according to the dominant factors determined following the analysis of factors that directed them to start an entrepreneurship career. Figure6 shows the emergence of entrepreneurship in the Biga region. There are 7 different zones in the figure. Zone I displays the individuals who started their entrepreneurship career by taking over their family business. Zone II shows the individuals who had gained their experience by working with a master in a profession, and started their entrepreneurship career in the same sector. Zone III illustrates the individuals who started their enterprises based on information they collected around themselves or by formal education, rather than taking over their family business or working with a master craftsman. In zone IV, entrepreneurs taking over their family business as well as receiving their training by working with a master are shown. Zone V represents entrepreneurs having the characteristics of the entrepreneurs illustrated in Zone II and Zone III. Zone VI is related to entrepreneurs who started their enterprise by taking over their family business together with those depending on information they collected from people outside their family. Lastly, Zone VII is a mixed zone showing entrepreneurs having the characteristics of all three types.

Type I characterizes the entrepreneurs who took over their family business with the thought of sustaining family tradition and their father's profession. These entrepreneurs have taken over other firms. Entrepreneurs in Zone I are pure take-overs, starting their profession at an early age, and their role models are their fathers. In these 
factors, perceived feasibility, which is one of the antecedents of intentions, was affected positively by means of self efficacy. In Type II, entrepreneurs primarily grew up working with a master, and started their own business later. These entrepreneurs are called "Professional Entrepreneurs". Entrepreneurs in Zone II of the figure are pure professional entrepreneurs. Their role models are their masters in their profession, and they started their enterprises in the same sector in which their masters were already active. The relationship between experience-self efficacy-perceived feasibility is the basic correlation directing these entrepreneurs' behaviours. Zone IV is located at the intersection point of Type I and II. The entrepreneur in this zone took over the enterprise from his father, and his entrepreneurial behaviour is in fact directed by two triggering factors. He started his entrepreneurship career by using the gold ornaments given as a gift during his wedding for his capital, but upon problems in his father's enterprise he came for help to his father's enterprise, and he took it over later. This entrepreneur's master in his profession is his mother, and he gained his working skills by working with his mother. Therefore, he possesses the characteristics of both types. Remarks made for Type I and II are also valid for this type. There is no master-apprentice relation or take over in Type III. The fundamental factor guiding the entrepreneurial behaviours of these entrepreneurs is information. Thus they are named as "Informational Entrepreneurs". Entrepreneurs in Zone III of the figure are pure informational entrepreneurs. Experience is not dominant in this zone. Entrepreneurial behaviours are exhibited with the information collected from people around the entrepreneur. In Case 1, 2, 10 and 20, there is a relationship of education-information-experience-entrepreneurial behaviour. Case 4 has a relationship of information-experience-entrepreneurial behaviour; there is also a relationship of information-entrepreneurial behaviour in Case 17. Role models of these entrepreneurs are in different sectors, and they have only an encouraging effect. The triggering factor affecting their formation of entrepreneurial behaviour is the information they collected from their circles, and it primarily affects the perceived desirability for preferring entrepreneurship career. Zone V is located at the intersection point of Type II and III. No priority is available between perceived desirability and perceived feasibility in the formation of entrepreneurial behaviour in this zone, and a full interaction is observed in the zone. While Case 13 and 22 show experience-triggering events-entrepreneurial behaviour, Case 12 and 14 show information-precipitating factors-experience.

Although the interaction of antecedents among themselves in the formation of intentions related to behaviour is not stated clearly in literature, this analysis aimed to determine the predominant attitude between perceived feasibility and desirability attitudes by using findings. This analysis also aimed to present the role of the precipitating factors as a moderator based on typecasting acquired from the analysis of interviews.

\section{References}

Ajzen, I. (1991). The theory of planned behaviour. Organizational Behavior and Human Decision Processes, 50, 179-211. http://dx.doi.org/10.1016/0749-5978(91)90020-T

Baron, R. A., \& Ward, T. B. (2004). Expanding entrepreneurial cognition's toolbox: Potential contributions from the field of cognitive science. Entrepreneurship Theory and Practice, 28, 553-573. http://dx.doi.org/10.1111/j.1540-6520.2004.00064.x

Biondo, J., \& Macdonald, A. P. Jr. (1971). Internal-external locus of control and response to influence attempts. Journal of Personality, 39, 407-419. http://dx.doi.org/10.1111/j.1467-6494.1971.tb00051.x

Bird, B. J. (1988). Implementing entrepreneurial ideas: The case for intentions. Academy of Management Review, 13, 442-453. http://dx.doi.org/10.5465/AMR.1988.4306970

Bird, B. J. (1992). The operation of intentions in time the emergence of the new venture. Entrepreneurship Theory and Practice, 17(1), 11-20.

Bird, B., \& Jeline, M. (1988). The operation of entrepreneurial intentions. Entrepreneurship Theory and Practice, 13(2), 21-29.

Boone, C., Brabander, D. B., \& Witteloostuijn, A. V. (1996). CEO locus of control and small firm performance: An integrative framework and empirical test. Journal of Management Studies, 33(5), 667-699. http://dx.doi.org/10.1111/j.1467-6486.1996.tb00814.x

Boyd, G. N., \& Vozikis, G. S. (1994). The influence of self-efficacy on the development of entrepreneurial intentions and actions. Entrepreneurship Theory and Practice, 18(4), 63-77.

Brockhaus, R. H. (1975). I-E locus of control scores as predictors of entrepreneurial intentions. Academy of Management Proceedings, 433-435. http://dx.doi.org/10.5465/AMBPP.1975.4990354

Brockhaus, R. H. (1980a). Risk taking propensity of entrepreneurs. Academy of Management Journal, 23, 


\section{9-520. http://dx.doi.org/10.2307/255515}

Brockhaus, R. H. (1980b). Psychological and environmental factors which distinguish the successful from the unsuccessful entrepreneur a longitudinal study. Academy of Management Proceedings, 368-372. http://dx.doi.org/10.5465/AMBPP.1980.4977943

Brockhaus, R. H., \& Horwitz, P. S. (1986). The psychology of the entrepreneur. In Sexton, D. L., \& Smilor, R. W. (Eds.), The Art and The Science of Entrepreneurship (pp. 25-48).

Brockhaus, R. H., \& Nord, W. R. (1979). An exploration of factors affecting the entrepreneurial decision personal characteristic vs. environmental conditions. Academy of Management Proceedings, 364-368. http://dx.doi.org/10.5465/AMBPP.1979.4977621

Bull, I., \& Willard, G. (1995). Towards a theory of entrepreneurship. In Bull, I., Howard, T., \& Willard, G. (Eds.), Entrepreneurship Perspectives on Theory Building (pp. 1-16). Elsevier Science: England.

Busenitz, L. W., \& Barney, J. B. (1997). Differences between entrepreneurs and managers in large organizations biases and heuristics in strategic decision-making. Journal of Business Venturing, 12, 9-30. http://dx.doi.org/10.1016/S0883-9026(96)00003-1

Busenitz, L. W., \& Lau, C. (1996). A cross-cultural cognitive model of new venture creation. Entrepreneurship Theory and Practice, 20(4), 25-39.

Carolis, D. M. D., \& Saparito, P. (2006). Social capital, cognition, and entrepreneurial opportunities: A theoretical framework. Entrepreneurship Theory and Practice, 30, 41-56. http://dx.doi.org/10.1111/j.1540-6520.2006.00109.x

Cervone, D. (2000). Thinking about self efficacy. Behavior Modification, 24, 30-56.

Cooper, A. (1986). Entrepreneurship and High Technology. In Sexton, D. L., \& Smilor, R. W. (Eds.), The Art and The Science of Entrepreneurship (pp. 153-180). Ballinger Publishing Company: Cambridge Massachusetts.

Cromie, S. (2000). Assessing entrepreneurial inclinations some approaches and empirical evidence. European Journal of Work and Organizational Psychology, 9(1), 7-30. http://dx.doi.org/10.1080/135943200398030

Decarlo, J. F., \& Lyons, P. R. (1979). A Comparison of selected personal characteristics of minority and non-minority female entrepreneurs. Academy of Management Proceedings, 369-373. http://dx.doi.org/10.5465/AMBPP.1979.4977629

Decarlo, J. F., \& Lyons, P. R. (1980). Toward a contingency theory of entrepreneurship. Journal of Small Business Management, 18(3), 37-42.

Dimov, D. (2007a). Beyond the single-person, single-insight attribution in understanding entrepreneurial opportunities. Entrepreneurship Theory and Practice, 31, 713-731. http://dx.doi.org/10.1111/j.1540-6520.2007.00196.x

Dimov, D. (2007b). From opportunity insight to opportunity intention: The importance of person-situation learning match. Entrepreneurship Theory and Practice, 31, 561-583. http://dx.doi.org/10.1111/j.1540-6520.2007.00188.x

Eden, D., \& Aviram, A. (1993). Self efficacy training to speed reemployment: helping people to help themselves. Journal of Applied Psychology, 78, 352-360. http://dx.doi.org/10.1037/0021-9010.78.3.352

Eisenhardt, K. (1989). Building theories from case study research. Academy of Management Review, 14, 532-550. http://dx.doi.org/10.5465/AMR.1989.4308385

Erikson, T. (2003). Towards A taxonomy of entrepreneurial learning experiences among potential entrepreneurs. Journal of Small Business And Enterprise Development, 10, 106-112. http://dx.doi.org/10.1108/14626000310461240

Gartner, W. B. (1989). Some suggestions for research on entrepreneurial traits and characteristics. Entrepreneurship Theory and Practice, 14(1), 27-37.

Gartner, W. B. (2001). Is there an elephant in entrepreneurship? Blind assumptions in theory development. Entrepreneurship Theory and Practice, 25(4), 27-39.

Hansemark, O. C. (2003). Need for achievement, locus of control and the prediction of business start-ups a

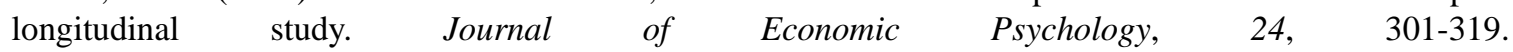
http://dx.doi.org/10.1016/S0167-4870(02)00188-5 
Hmieleski, K. M., \& Corbett, A. C. (2006). Proclivity for improvisation as a predictor of entrepreneurial intentions. Journal of Small Business Management, 44(1), 45-63. http://dx.doi.org/10.1111/j.1540-627X.2006.00153.x

Holcomb. T. R., Ireland, R. D., Holmes, R. M. Jr., \& Hitt, M. A. (2009). Architecture of entrepreneurial learning: Exploring the link among heuristics, knowledge, and action. Entrepreneurship Theory and Practice, 33, 167-192. http://dx.doi.org/10.1111/j.1540-6520.2008.00285.x

Hornaday, J. A., \& Aboud, J. (1971). Characteristics of successful entrepreneurs. Personnel Psychology, 24(2), 141-153. http://dx.doi.org/10.1111/j.1744-6570.1971.tb02469.x

Hornaday, R. W. (1992). Thinking about entrepreneurship a fuzzy set approach. Journal of Small Business Management, 30(4), 12-23.

Hoy, F., \& Verser, T. G. (1994). Emerging business, emerging field entrepreneurship and the family firm. Entrepreneurship Theory and Practice, 19(1), 9-23.

Hull, D. L., Bosley, J. J., \& Udell, G. G. (1980). Renewing the hunt for the heffalump identifying potential entrepreneurs by personality characteristics. Journal of Small Business Management, 18(1), 11-18.

Jenks, L. H. (1950). Approaches to entrepreneurial personality. Explorations in Entrepreneurial History, 2(2), 91-99.

Jennings, D. F., \& Zeithami, C. P. (1983). Locus of control: A review and directions for entrepreneurial research. Academy of Management Proceedings, 417-421. http://dx.doi.org/10.5465/AMBPP.1983.4976387

Katz, J. A. (1992). A psychological cognitive model of employment status choice. Entrepreneurship Theory and Practice, 17(1), 29-37.

Kaufmann, P. J., Welsh, D. H. B., \& Bushmarin, N. V. (1995). Locus of control and entrepreneurship in the Russian republic. Entrepreneurship Theory and Practice, 20(1), 43-56.

Keh, H. T., Foo, M. D., \& Lim, B. C. (2002). Opportunity evaluation under risky conditions the cognitive processes of entrepreneurs. Entrepreneurship Theory and Practice, 27(2), 125-148. http://dx.doi.org/10.1111/1540-8520.00003

Kemelgor, B. H. (1985). A Longitudinal analysis of the transition from organization man to entrepreneur. Academy of Management Proceedings, 67-70. http://dx.doi.org/10.5465/AMBPP.1985.4978504

Koh, H. C. (1996). Testing hypotheses of entrepreneurial characteristics a study of Hong Kong MBA students. Journal of Managerial Psychology, 11(3), 12-22. http://dx.doi.org/10.1108/02683949610113566

Kolvereid, L. (1996). Prediction of employment status choice intentions. Entrepreneurship: Theory and Practice, 21(1), 47.

Krueger, N. (1993). The impact of prior entrepreneurial exposure on perceptions of new venture feasibility and desirability. Entrepreneurship Theory and Practice, 18(1), 5-21.

Krueger, N. F. Jr. (2000). The cognitive infrastructure of opportunity emergence. Entrepreneurship Theory and Practice, 24(3), 5-23.

Krueger, N. F. Jr., \& Brazeal, D. V. (1994). Entrepreneurial potential and potential entrepreneurs. Entrepreneurship: Theory and Practice, 18(3), 91-104.

Krueger, N. F. Jr., \& Carsrud, A. L. (1993). Entrepreneurial intentions: Applying the theory of planned behaviour. Entrepreneurship \& Regional Development, 5, 315-330. http://dx.doi.org/10.1080/08985629300000020

Krueger, N. F. Jr., Reilly, M. D., \& Carsrud, A. (2000). Competing models of entrepreneurial intentions. Journal of Business Venturing, 15(5-6), 411-432. http://dx.doi.org/10.1016/S0883-9026(98)00033-0

Littunen, H. (2000). Entrepreneurship and the characteristics of the entrepreneurial personality. International


http://dx.doi.org/10.1108/13552550010362741

Littunen, H., \& Storhammar, E. (2000). The indicators of locus of control in the small business context. Journal of Enterprising Culture, 8(4), 343-360. http://dx.doi.org/10.1142/S0218495800000188

Litzinger, W. D. (1965). The motel entrepreneur and the motel manager. Academy of Management Journal, 8(4), 268-281. http://dx.doi.org/10.2307/255343

Markman, G. D., Balkin, D. B., \& Baron, R. A. (2002). Inventors and new venture formation: The effects of 
general self efficacy and regretful thinking. Entrepreneurship Theory and Practice, 27(2), 149-165. http://dx.doi.org/10.1111/1540-8520.00004

Marsh, H. W., \& Richards, G. E. (1987). The multidimensionality of the rotter i-e scale its higher-order structure: An application of confirmatory factor analysis. Multivarite Behavioral Research, 22(1), 39-69. http://dx.doi.org/10.1207/s15327906mbr2201_3

Matthews, C., Moser, H., \& Steven, B. (1995). Family background and gender: Implications for interest in small firm ownership. Entrepreneurship \& Regional Development, 7, 365-377. http://dx.doi.org/10.1080/08985629500000023

Mescon, T., \& Montanari, J. N. (1981). The personalities of independent and franchise entrepreneurs, an empirical analysis of concepts. Journal of Enterprise Management, 3, 413-417.

Mitchell, R. K., Busenitz, L., Lant, T., McDougall, P. P., Morse, E. A., \& Smith, B. J. (2002). Toward a theory of entrepreneurial cognition rethinking the people side of entrepreneurship research. Entrepreneurship Theory and Practice, 27(2), 93-104. http://dx.doi.org/10.1111/1540-8520.00001

Mitchell, R. K., Busenitz, L., Lant, T., McDougall, P. P., Morse, E. A., \& Smith, J. B. (2004). The Distinctive and inclusive domain of entrepreneurial cognition research. Entrepreneurship Theory and Practice, 28, 505-518. http://dx.doi.org/10.1111/j.1540-6520.2004.00061.x

Mitchell, T. R., Smyser, C. M., \& Weed, S. E. (1975). Locus of control: Supervision and work satisfaction. Academy of Management Journal, 18, 623-631. http://dx.doi.org/10.2307/255692

Morris, M. H., Lewis, P. S., \& Sexton, D. L. (1994). Reconceptualizing entrepreneurship an input-output perspective. S.A.M. Advanced Management Journal, 59(1), 21-31.

Ozgen, E., \& Baron, R. A. (2007). Social sources of information in opportunity recognition: Effects of mentors, industry networks, and professional forums. Journal of Business Venturing, 22, 174-192. http://dx.doi.org/10.1016/j.jbusvent.2005.12.001

Pandey, J., \& Tewary, N. B. (1979). Locus of control and achievement values of entrepreneurs. Journal of Occupational Psychology, 52(2), 107-111. http://dx.doi.org/10.1111/j.2044-8325.1979.tb00446.x

Pearson, C. A. L., \& Chatterjee, S. R. (2001). Differences and similarities of entrepreneurial characteristics in a diverse social setting-evidence from Australian and Singaporean managers. Journal of Enterprising Culture, 9(3), 273-289. http://dx.doi.org/10.1142/S0218495801000158

Perry, C., Meredith, G., \& Cunnington, J. H. (1988). Relationship between small business growth and personal characteristics of owner/managers in Australia. Journal of Small Business Management, 26(2), 76-79.

Peterman, N. E., \& Kennedy, J. (2003). Enterprise education influencing students perceptions of entrepreneurship. Entrepreneurship Theory and Practice, 28(2), 129-144. http://dx.doi.org/10.1046/j.1540-6520.2003.00035.x

Pines, H. A., \& Julian, J. W. (1972). Effects of task and social demands on locus of control differences in information processing. Journal of Personality, 40, 407-416. http://dx.doi.org/10.1111/j.1467-6494.1972.tb00070.x

Robinson, P. B., Stimpson, D. V., Huefner, J. C., \& Hunt, K. H. (1991). An attitude approach to the prediction of entrepreneurship. Entrepreneurship Theory and Practice, 15(4), 13-31.

Schaver, K. G., \& Scott, L. R. (1991). Person, process, choice the psychology of new venture creation. Entrepreneurship Theory and Practice, 16(2), 23-45.

Schere, J. L. (1982). Tolerance of ambiguity as a discriminating variable between entrepreneurs and managers. Academy of Management Proceedings, 404-408. http://dx.doi.org/10.5465/AMBPP.1982.4976860

Scherer, R. F., Adams, J. S., Carley, S. S., \& Wiebe, F. A. (1989). Role model performance effects on development of entrepreneurial career preference. Entrepreneurship Theory and Practice, 13(3), 53-71.

Schneider, S. C., \& Angelmar, R. (1993). Cognition in organizational analysis who's minding the store. Organization Studies, 14, 347-374. http://dx.doi.org/10.1177/017084069301400302

Schrage, H. (1965). The RD and entrepreneur profile of success. Harvard Business Review, 43(6), 56-69.

Schwenk, C. R. (1984). Cognitive simplification process in strategic decision-making. Strategic Management Journal, 5(2), 111-128. http://dx.doi.org/10.1002/smj.4250050203 
Scott, M. G., \& Twomey, D. F. (1988). The long term supply of entrepreneurs: Students career aspirations in relation to entrepreneurship. Journal of Small Business Management, 26(4), 5-13.

Sexton, D. L., \& Bowman, N. (1983). Determining entrepreneurial potential of students. Academy of Management Proceedings, 408-412. http://dx.doi.org/10.5465/AMBPP.1983.4976385

Shapero, A. (1982). Social Dimensions of Entrepreneurship. In Kent, C., Sexton, D., \& Vesper, K. (Eds.), The Encyclopedia of Entrepreneurship (pp. 72-90). Prentice-Hall: Englewood Cliffs.

Shepherd, D. A., \& Krueger, N. F. (2002). An intention-based model of entrepreneurial teams' social cognition. Entrepreneurship Theory and Practice, 27(2), 167-185. http://dx.doi.org/10.1111/1540-8520.00005

Shook, C. L., Priem, R. L., \& Mcgee, J. E. (2003). Venture creation and the enterprising indivudual a review and synthesis. Journal of Management, 29(3), 379-399. http://dx.doi.org/10.1016/S0149-2063_03_00016-3

Simon, M., \& Houghton, S. M. (2002). The relationship among biases, misperceptions, and the introduction of pioneering products examining differences in venture decision contexts. Entrepreneurship Theory and Practice, 27(2), 105-125. http://dx.doi.org/10.1111/1540-8520.00002

Simon, M., Houghton, S. M., \& Aquino, K. (2000). Cognitive biases, risk perception, and venture formation how individuals decide to start companies. Journal of Business Venturing, 15, 113-134. http://dx.doi.org/10.1016/S0883-9026(98)00003-2,

Timmons, J. A. (1986). Growing up Big: Entrepreneurship and the Creation of High-Potential Ventures. In Sexton, D. L. \& Smilor, R. W. (Eds.), The Art and The Science of Entrepreneurship (pp. 223-239). Cambridge Massachusetts: Ballinger Publishing Company.

Townsend, D. M., Busenitz, L. W., \& Arthurs, J. D. (2010). To start or not to start: Outcome and ability expectations in the decision to start a new venture. Journal of Business Venturing, 25, 192-202. http://dx.doi.org/10.1016/j.jbusvent.2008.05.003

Ucbasaran, D., Wright, M., \& Westhead, P. (2003). A longitudinal study of habitual entrepreneurs: Starters and acquirers. Entrepreneurship \& Regional Development, 15, 207-228. http://dx.doi.org/10.1080/08985620210145009

Uygun, R. (2006). Türkiye’de girisimcilik kültürünü yonlendiren oncü girisimciler ve ibrahim bodur modeli. (Pioneering entrepreneurs who orientate entrepreneurial culture in Turkey and the Ibrahim Bodur model) Canakkale Onsekiz Mart University, Social Sciences Institution, Canakkale, Unpublished Master Thesis.

Vaghely, I. P., \& Julien, P. A. (2010). Are opportunities recognized or constructed? An information perspective on entrepreneurial opportunity identification. Journal of Business Venturing, 25, 73-86. http://dx.doi.org/10.1016/j.jbusvent.2008.06.004

Yin, R. (1989). Case study research, design and methods (2nd Ed.). Beverly Hills, CA: Sage.

Zuckerman, M., \& Gerbasi, K. C. (1977). Belief in internal control or belief in a just world: The use and misuse of the i-e scale in prediction of attitudes and behaviour. Journal of Personality, 45, 356-378. http://dx.doi.org/10.1111/j.1467-6494.1977.tb00158.x 